\section{No Excuses:}

\section{A Brief History of Playing Through Risk in College Football}

\author{
Kathleen Bachynski
}

Keywords: College Sports, Ethics, Injury, Football, Risk

Abstract: Celebrations of playing through risk, skepticism of athletes perceived as faking injuries, unregulated training regimens, the mythos of amateurism, and lack of accountability for preventable health harms have long characterized many college football programs. Setting policies that effectively prioritize player health will require taking this history into account.

I $\mathrm{n}$ the early 1930s, the American Football Coaches Association (AFCA) was closely tracking public alarm over the hazards of college football. Calls for reform grew particularly loud following the death of Richard Brinsley Sheridan, Jr. in 1931. In the fourth quarter of that year's Army-Yale football game, the young cadet sustained a broken neck while making a tackle. He never regained consciousness and died several days later. ${ }^{1}$ Dr. Mal Stevens, then-president of the AFCA, warned attendees at the association's annual meeting that "all the furore" would adversely affect recruitment efforts: "we can anticipate that a lot of mothers are not going to let their sons play football."2 The public might begin to perceive the sport as unacceptably dangerous.

In response, Stevens announced that the AFCA would initiate a survey of injuries and fatalities. ${ }^{3} \mathrm{He}$ also co-authored a 1933 text, The Control of Football Injuries, to directly address safety concerns. Reviewers at the time noted that this work "grew out of the criticism of the game of football and its associated injuries." Alongside its specific health guidance, ranging from best dietary practices to how to set up a locker room, The Control of Football Injuries also reveals deep-seated beliefs about player safety. These included the conviction that some players were prone to fake injuries, and that a stoic approach was appropriate for minor or commonplace injuries that were presumably of little consequence.

Even in a medical text written in the wake of a highly publicized college player's death, physicians reinforced the view that exaggerating or faking an injury was shameful. In conjunction with powerful financial and institutional pressures, this longstanding cultural perception continues to inform attitudes toward risk in college sports today. From brain trauma to heat stroke, and most recently Covid-19, such nar-

Kathleen Bachynski, Ph.D., M.P.H., is an Assistant Professor of Public Health at Muhlenberg College. 
ratives have facilitated the exposure of young athletes to the risks of serious health harms under the aegis of educational institutions. Setting policies that effectively prioritize player health will require taking this history into account.

\section{"A Spartan Attitude"}

In their overview of football's hazards, Dr. Stevens and his colleague Dr. Winthrop Morgan Phelps highlighted the importance of promptly reporting and treating injuries. They warned against a popular idea of "guts" that might incline athletes to attempt playing through serious injuries. ${ }^{5}$ On this view, hiding an injury and continuing to compete was a sign of honor.

While acknowledging that this notion was a mistake, Stevens and Phelps contended that attempting to conceal an injury was "more admirable" than "to feign one." Consequently, they urged athletic trainers to adopt a "Spartan attitude" toward "ordinary injuries." Explaining that younger boys were particularly apt to fake injuries, the doctors attributed this tendency to boys' desire for publicity, and in some cases an attempt to escape from their failure to develop into first class athletes. "A Spartan gains the respect and affection of his intimates and the malingerer only incurs their contempt."' Even this overview of football injuries prompted in part by a player's death reminded readers that seeking treatment for a small or non-existent injury was associated with disgrace. To help prevent such malingering on the part of athletes, Stevens and Winthrop advised that physicians and trainers curtail "sentimentality and self-pity in private or public."7 While the two doctors urged athletes to neither hide nor feign injuries, they reserved their sharpest censure for the "pseudo-athletes" they claimed engaged in the latter.

Such suspicions of feigned injuries often accompanied beliefs that competitive sports helped build moral character in ways that included playing through injuries. These norms permeated understandings of the "life lessons" imparted by football. As Carl Snavely, the head football coach at Cornell University, put it in 1936, "If these values can be taught on the field of play rather than on the field of war, what difference does it make if the boy gets a few bruises and sprains?"8 Seemingly minor injuries were considered negligible in comparison to such values as courage, discipline and loyalty that coaches believed football imparted.

The specific social concerns put forward to justify the importance of a stoic form of character building through contact sports varied over the decades. For example, the threat of totalitarianism in the late $1930 \mathrm{~s}$ and 1940s contributed to an emphasis on football as a means to prepare boys to defend the country. ${ }^{9}$ While competitive athletics offered a way to teach young athletes desired social values at a lower risk than active military service, key virtues in both contexts included the importance of withstanding physical risk and a willingness to sacrifice for the greater good. In 1940, Lafayette College president William Lewis Mather told the AFCA that

It is trite, of course, to say that the Battle of Waterloo was won on the playing fields of great private schools, of Eton, in England; but it isn't trite to say that the athletic officers of the American colleges today have it in their hands to decide whether or not the young men of America will go forth prepared, either for warfare when the guns are booming, or in the other warfare that we must face, economic and social and political. $^{10}$

In the 1950s, Cold War anxieties and social concerns, such as the potential for juvenile delinquency, loomed larger after the booming guns of World War II had ceased. ${ }^{11}$ In 1958, Brandeis football coach Benny Friedman stated that rather than joining a gang or wearing a leather jacket, boys "should be out on the playing fields, knocking heads." 12 The perceived character building benefits of football were so powerful that they enabled coaches to frame hits to players' heads as healthy and as a far better alternative to life on the streets. Sports medicine doctors promulgated similar views. Physician Thomas B. Quigley, former chair of the American Medical Association's Committee on the Medical Aspects of Sports, wrote in 1966 that "the playing field is better than hot rod activities, or the tavern."13 Teen car culture, gangs, joy riding, and drinking were all associated with irresponsibility and idleness. Feigning an injury to avoid football participation was seen as particularly suspicious in a context where the specific character building advantages of the sport were explicitly framed in opposition to the indolence of the streets and barrooms.

With "knocking heads" conceived as a more wholesome activity for youth than donning a leather jacket, coaches often expressed greater concern about the possibility of an athlete malingering than the possibility that he might have sustained brain injury. Writing in the Journal of School Health in 1953, physical educator R. T. DeWitt described witnessing one high school football player fail to get up after a hard tackle during a practice session. The head coach, however, "apparently believed that the boy was feigning unconsciousness" and sought to pull him to his feet and insist that he return to the game..$^{14}$ DeWitt made clear that it was obvious to him, "a lay person having only 
a smattering of knowledge regarding the symptoms of brain injury, that something was wrong with the boy." The player was subsequently diagnosed with a concussion. DeWitt described other similar incidents, and contended that only a national movement might effectively address the flawed social structure in which authorities responsible for player safety rationalized away serious injuries. ${ }^{15}$

The refocusing of interscholastic athletics that DeWitt called for did not occur. Instead, for decades, the hazards of football provided not only entertainment appeal, but also prominently featured in coaches' justifications of the sport's moral benefits. The "bumps and bruises" of football were characterized as inherent to the game and even as crucial to a
Dennison's widow lost the case, and the "student athlete" defense featured in subsequent influential cases involving the NCAA. ${ }^{18}$ The framing of college athletics as a noble exemplar of amateurism persisted even as the money involved in big-time college sports grew. Notably, a 1984 Supreme Court decision contended that the NCAA "plays a critical role in the maintenance of a revered tradition of amateurism in college sports." 19 In this case, the Court ruled that individual colleges and universities could negotiate their own television contracts, opening the college football television market to free competition with multimillion dollar contracts at stake. Yet writing for the majority in this decision, Justice John Paul Stevens emphasized that "the preservation of the student-ath-

\section{In conjunction with these social attitudes toward risk, financial incentives crucially motivated the NCAA to eschew legal responsibility for player injuries. The very history of the term "student athlete" derives from the NCAA's effort to avoid paying worker's compensation benefits.}

team's success. ${ }^{16}$ College administrators and policymakers did not mandate national protocols to prevent injuries. Instead, persistent narratives that relatively young, healthy athletes could and should overcome the hazards of competitive athletics contributed to the absence of more rigorous safety protections for athletes. In a culture that celebrated "knocking heads" as wholesome for football players, a "Spartan attitude" predominated and policies to minimize the physical risks were not prioritized.

\section{"A Revered Tradition"}

In conjunction with these social attitudes toward risk, financial incentives crucially motivated the NCAA to eschew legal responsibility for player injuries. The very history of the term "student athlete" derives from the NCAA's effort to avoid paying worker's compensation benefits. In the 1950s, the widow of Ray Dennison, an athlete who died of a head injury sustained while playing football for the Fort Lewis A\&M Aggies, filed for compensation. As writer Taylor Branch explained in an influential 2011 commentary, coining the term "student athlete" helped the NCAA successfully contend to the Colorado Supreme Court that there was no employer-employee relationship between students and their schools. Consequently, colleges were "not in the in the football business" and did not have a duty to compensate athletes for injuries. ${ }^{17}$ lete in higher education adds richness and diversity to intercollegiate athletics" and that this ideal was key to the place of college sports in American life. ${ }^{20}$

These two ideologies - the belief that the NCAA was responsible for upholding ideals of amateurism, and the view that one of the key lessons of college sports was how to persevere through adversity - both profoundly influenced expectations that athletes play through risk. From the NCAA's inception following a spate of high-profile college football injuries and deaths in the early twentieth century, the physical risks of athletics were treated as essential and desirable components of the game. In 1905, President Roosevelt, who helped lead the reforms, gave a widely quoted commencement address at Harvard in which he affirmed his belief in "rough sports." He expressed his scorn for young men who avoided risk while wrapped "in cotton wool," adding that he had "a hearty contempt for him if he counts a broken arm or collar bone as of serious consequence, when balanced against the chance of showing that he possesses hardihood, physical address, and courage."21 These were the qualities that college sports leaders sought to inculcate in students. Conversely, the message to athletes who avoided risk, or who took injuries seriously, was that they would be subject to disdain.

One of the life lessons college amateurs were expected to learn, then, was that broken bones were 
negligible in comparison to ideals of "hardihood" and toughness. Yet a longstanding view remains that the NCAA was established in order to safeguard athletes' health. The NCAA itself has promulgated this narrative, contending on its website that the association was founded in 1906 "to keep college athletes safe." 22 As Michael Oriard has argued, however, the early twentieth century reforms that led to the creation of the NCAA sought to address some of football's most brutal elements without lessening its spectator appeal, and ultimately "without making it truly safer for the players." ${ }^{23}$ The NCAA's failure to implement enforceable safety protocols is consistent with its founders' view that conceptions of courage ultimately took priority over injury prevention. Through the present, American college sports programs continue to lack basic oversight to protect players. Notably, "there are no NCAA rules with penalties governing coaches' behavior and player injuries, only guidelines." ${ }^{24}$ In 2021, NCAA president Mark Emmert testified before the U.S. Senate that there was no national enforcement system for health protocols. ${ }^{25}$

Occasionally, legal or policy pressures have prompted the NCAA to mandate measures to protect athletes against life-threatening conditions. For example, a legal settlement with the family of Rice football player Dale Lloyd II, who collapsed and subsequently died from complications related to sickle cell trait in 2006, led the NCAA to implement a universal screening program for this genetic condition. ${ }^{26}$ Apart from such reactive measures, however, neither the NCAA nor policymakers have required proactive, national policies to protect athletes from the broad range of known risks associated with college sports. In this vacuum of accountability, nearly a century after Sheridan, Jr.s death, colleges have frequently gambled with athletes' welfare. This policy gap has proved especially consequential for college football, where both the physical hazards and the financial stakes are particularly high. The risks range from the cumulative and long-term - notably repeated traumatic brain injuries - to the immediate and devastating.

Heatstroke fatalities are a particularly striking example of the latter category because they are entirely preventable through proper training precautions. Since the 2001 death of Minnesota Vikings offensive tackle Korey Stringer drew attention to the issue, no NFL players have subsequently died of heatstroke. ${ }^{27}$ Yet amateur college players lack the workplace protections available to professional athletes. Instead, many college football coaches continue to insist on high-risk preseason workouts that are "deeply embedded in the football culture," based on the belief that pushing players to their physiological limits will lead to "mental and physical toughness, discipline, and accountability." ${ }^{28}$ In the absence of enforceable safety standards, as athletic trainer Scott Anderson has observed, an average of two NCAA football players die these types of preventable deaths each season. ${ }^{29}$

The 2018 heatstroke death of University of Maryland offensive lineman Jordan McNair drew public attention to the broader toxic culture surrounding such high-risk workouts. ESPN described an atmosphere of fear and belittlement, in which a player deemed overweight was forced to eat candy bars and in which players unable to complete particular workouts or drills were subjected to taunts mocking their masculinity. ${ }^{30}$ Underlying such an environment was the threat of players being perceived as weak, inadequate or exaggerating injuries. Centuries-old American histories of racist stereotypes meant that black athletes were more likely to be perceived by white coaches, staff and spectators as lazy or lacking a work ethic. ${ }^{31}$ As writer Tyler Tynes observed in an essay on McNair's death, black athletes remain disproportionately subjected to the expectation that they repeatedly "prove they are not weak," to deadly effect. ${ }^{32}$

In a training environment such as Maryland's, staff disbelieved the most blatant evidence of serious health harms. For example, a former Maryland player recalled witnessing an injured player pass out during a tug-of-war competition: "I saw his body slowly giving away, and the strength coach was like, 'Keep pulling, keep pulling!"'33 Even a player in the process of losing consciousness might be accused of malingering and expected to continue with a drill. Implicit bias makes the pain and distress of black athletes even more likely to be disregarded or mistrusted. These factors have all contributed to a college sports environment where "kids like McNair will die in the hot sun," with the coaches responsible for their well-being subsequently offered jobs elsewhere. ${ }^{34}$

Moreover, the tragic death toll of college football represents only the tip of the iceberg when it comes to the policy vacuum that fails to protect athletes. While student deaths are the most devastating and visible outcome of unsafe sports environments, many more students are regularly exposed to serious non-fatal risks while competing. Brain injuries in football and associated neurological diseases, from chronic traumatic encephalopathy to amyotrophic lateral sclerosis, have received growing medical and legal attention in recent years. ${ }^{35}$ In addition, bone and joint injuries remain extremely common in this collision sport. A 2016 study found that on average, half of college football players experienced at least one injury per season that required an absence of at least one day, representing a high burden of injury. ${ }^{36}$ 


\section{"A Little Covid Problem"}

Celebrations of overcoming physical risk, skepticism of faking or exaggerating injuries, unregulated training regimens, the mythos of amateurism, and lack of accountability for preventable health harms have long characterized many college football programs. In 2020, a novel pandemic virus entered into this already dangerous mix. In many ways, rather than forcing a reckoning with this history, the virus that causes Covid-19 was simply added to the lengthy list of preventable health harms to which players were routinely exposed. ${ }^{37}$ Despite the cautions of public health experts and numerous outbreaks associated with summer football workouts, many administrators determined to proceed with the fall 2020 season. As the athletic director at University of California, Berkeley put it, "we're going to make it work. And we're not going to be fazed by a little Covid problem."38

Not only did numerous conferences strive to "play through" the virus in the fall 2020, but some put forth the view that pre-season exposure to the virus and subsequent immunity would yield a "competitive advantage" for teams. ${ }^{39}$ Clemson University head football coach Dabo Swinney even expressed skepticism of game cancellations due to Covid-19 protocols: "COVID was just an excuse to cancel the game." 40 Teams that bowed out of a match due to Covid-19 protocols were accused of faking cases..$^{41}$ Guidelines that prioritized caution following a positive Covid-19 test contradicted the "no excuses" ethos that has been associated with college football for decades.

The NCAA did not track Covid-19 cases among athletes at its member schools. By December 2020, the New York Times estimated that at least 6,629 college athletes, coaches and staff had tested positive for coronavirus. Yet numerous schools failed to share data, making the total number unknowable. ${ }^{42}$ Although many athletes who contracted Covid-19 had relatively mild symptoms, others experienced season- and even career-ending symptoms. For example, after testing positive for Covid-19, Clemson defensive end Justin Foster struggled with ongoing symptoms and missed all of the fall 2020 season. Due to a combination of asthma, allergies and Covid-19, he announced his decision to retire from football in February 2021. "The decision came after months of recovery and treatment," he explained. ${ }^{43}$

This most recent failure to protect athletes from known, direct risks to their short and long term health is consistent with the past behavior of the governing bodies of college sports. It is also consistent with longstanding cultural expectations that athletes "play on" and overcome physical risk. Of course, the nature of an infectious disease meant that the hazard was not lim- ited to the playing field. The Covid-19 risks imposed upon athletes extended "outward to trainers, coaches, staff, families, and ultimately the broader community," making the failure to prioritize athlete health all the more consequential. ${ }^{44}$ Yet consistent with its approach to brain injuries, heat stroke and other health risks, the NCAA implemented no enforceable policies to control the spread of Covid-19. For instance, athletic programs did not have to conduct a minimum number of tests or adhere to consistent quarantine protocols. ${ }^{45}$

\section{Keeping College Athletes Safe}

Although health and safety policies for college athletes remain few and far between, hints of challenges to the NCAA's narratives surrounding the studentathlete tradition have begun to emerge. In June 2021, the Supreme Court ruled that college athletes could receive "enhanced education-related benefits," rejecting the NCAA's argument that such payments represented a threat to amateurism. ${ }^{46}$ But this decision did not address protections for athlete health. As Representative Lori Trahan (D-Lowell) observed, "we must go further by guaranteeing them [athletes] the right to organize and collectively bargain for the compensation, safety, and playing conditions they're owed." ${ }^{77}$ Martin McNair, the father of Jordan McNair, a college football player who died of heat stroke in 2018, expressed a similar view. "How do we pay a kid if we can't keep him safe?" he asked. ${ }^{48}$

Ninety years after the death of Sheridan, Jr., the NCAA remains unwilling and unable to ensure the basic safety of its participants. These failures have been particularly devastating for the health of football players engaged in a collision sport with little oversight for coaches and administrators who have failed to adhere to minimal safety standards. The preventable deaths of young athletes from heatstroke epitomize this institutional disregard for health.

Permanent change is necessary in order to truly make college athletes' health as well as the public's health a priority. But this will not happen without fundamentally reckoning with the values that celebrate "playing through" risk and that cast suspicion upon athletes who speak up about health hazards. ${ }^{49}$ Since the origins of both tackle football and the NCAA, overcoming physical hazard has been promoted as one of the key character building benefits of college sports. Consequently, to a great degree the possibility of an athlete shirking or receiving undue "coddling" has been regarded as a greater threat than depriving an athlete of needed medical attention..$^{50}$ Coaches and even doctors warned that feigning an injury was shameful and worthy of contempt. Under this prevailing framework, the alternative - acknowledging, treating, and ulti- 
mately preventing the routine hazards associated with football - might undermine the value system that had justified incorporating a collision sport into schools.

As the experience of athletic programs navigating Covid-19 has made clear, it is past time to insist that college sports leaders embrace and act upon another value system. To truly protect athletes, an entirely different set of "life lessons" from those associated with warfare and a "Spartan" mentality is required. For decades, coaches and administrators have claimed "no excuses" for athletes, even when their very physical safety was threatened. Instead, there ought to be no excuses for continuing to tolerate preventable deaths, acute injuries, and long-term chronic disease in institutions of higher education.

\section{Note}

The author has no conflicts to disclose.

\section{References}

1. K. Bachynski, No Game for Boys to Play: The History of Youth Football and the Origins of a Public Health Crisis (Chapel Hill: University of North Carolina Press, 2019).

2. "Report of Rules Committee," Athletic Journal 12, no. 7 (1932): 19-24, at 24

3. AFCA, Proceedings of the Treelfth Annual Meeting of the American Football Coaches Association, New York, December 27-28, 1932.

4. W. J. Stewart, "The Control of Football Injuries," American Journal of Public Health 23, no. 11 (1933): 1212-1213, at 1212.

5. M. A. Stevens and W. M. Phelps, The Control of Football Injuries (New York: A. S. Barnes, 1933): at 20-21.

6. See Stevens and Phelps, supra note 5, at 21.

7. See Stevens and Phelps, supra note 5, at 20.

8. "Value of Football to Education Cited," The Atlanta Constitution, December 29, 1936.

9. See Bachynski, supra note 1.

10. W. L. Mather, "Athletics and National Defense," address, 35th Convention of the NCAA and the AFCA (New York, December 30, 1940): at 8 .

11. J. Gilbert, A Cycle of Outrage: America's Reaction to the Juvenile Delinquent in the 1950 s (Oxford University Press, 1988).

12. B. Holbrook, "Friedman Raps Parents: Brandeis Coach Says Football Makes Men of Boys," Daily Boston Globe, October 28, 1958.

13. T. B. Quigley, "Contributions of Sports to Medicine," JAMA 197, no. 11 (1966): 161-162, at 162.

14. R. T. DeWitt, "Football Practices Show Need for Re-Orientation," Journal of School Health 23, no. 4 (1953): 117-119, at 117.

15. See DeWitt, supra note 14, at 117.

16. A. Parseghian, "Memories," Star-Gazette and Advertiser, December 3, 1966.

17. T. Branch, "The Shame of College Sports," Atlantic, October 2011, available at <https://www.theatlantic.com/magazine/ archive/2011/10/the-shame-of-college-sports/308643/> (last visited July 10, 2021).

18. See Branch, supra note 17.

19. NCAA v. Board of Regents of Univ. of Okla., 468 U.S. 85, 120 (1984).

20. F. Barbash, "Supreme Court Breaks NCAA Hold on Televised Football Games," Washington Post, June 28, 1984, available at <https://www.washingtonpost.com/archive/ politics/1984/06/28/supreme-court-breaks-ncaa-hold-ontelevised-college-football-games/35c9aace-baf7-4dfd-af14f7bcc702b0c9/> (last visited July 10, 2021).
21. T. Roosevelt, “The Harvard Spirit," Harvard Graduates' Magazine 14, no. 53 (1905): 1-9, at 5.

22. NCAA, "Well-Being," available at <https://www.ncaa.org/ health-and-safety> (last visited July 3, 2021).

23. M. Oriard, "Rough, Manly Sport and the American Way: Theodore Roosevelt and College Football, 1905," In Myths and Milestones in the History of Sport (Palgrave Macmillan, London: 2011): 80-105, at 102.

24. B. Strauss, "Complaints Against Nebraska Softball Coach Show College Athletes' Limited Options," Washington Post August 30, 2019, available at <https://www.washingtonpost. com/sports/2019/08/30/complaints-against-nebraska-softball-coach-show-college-athletes-limited-options/> (last visited July 10, 2021).

25. C. O'Brien, "NCAA President Mark Emmert Testifies on Capitol Hill, Asks Congress to Do his Job," The Daily Illini, June 10 2021, available at <https://dailyillini.com/sports/2021/06/10/ ncaa-president-mark-emmert-testifies-in-congress-asks-u-ssenators-his-job/> (last visited July 10, 2021).

26. B.A. Tarini, M.A. Brooks, and D. G. Bundy, "A Policy Impact Analysis of the Mandatory NCAA Sickle Cell Trait Screening Program," Health Services Research 47, no. 1 (2012): 446-461.

27. D. Marcus, "Three Years After His Death, Jordan McNair Foundation Trying to Save Lives by Preventing Heat Stroke," Baltimore Magazine, June 2, 2021, available at <https://www. baltimoremagazine.com/section/sports/jordan-mcnair-foundation-aims-to-educate-prevent-heat-stroke-illnesses/> (last visited July 3, 2021).

28. S. Anderson, "NCAA Football Off-Season Training: Unanswered Prayers ... A Prayer Answered," Journal of Athletic Training 52, no. 2 (2017): 145-148, at 146-147.

29. See Anderson, supra note 28.

30. "The Inside Story of a Toxic Culture at Maryland Football," ESPN, August 10, 2018, available at <https://www.espn.com/ college-football/story/_id/24342005/maryland-terrapinsfootball-culture-toxic-coach-dj-durkin> (last visited July 3, 2021).

31. G.B. Moskowitz and D. Carter, "Confirmation Bias and the Stereotype of the Black Athlete," Psychology of Sport and Exercise 36 (2018): 139-146.

32. T. Tynes, "Don't Forget Jordan McNair," The Ringer, January 10, 2019, available at <https://www.theringer. com/2019/1/10/18175709/jordan-mcnair-maryland-terrapins-ncaa-player-deaths > (last visited July 3, 2021).

33. See "The Inside Story," supra note 30.

34. See Tynes, supra note 32.

35. J. Schwartz, "The Lawyer Who Took on the NFL Over Concussions Has a New Strategy That Could Devastate the NCAA," Sports Illustrated, October 16, 2020, available at <https:// www.si.com/college/2020/10/16/ncaa-concussion-casesdaily-cover> (last visited July 3, 2021).

36. M.E. Steiner, B.D. Berkstresser, and L. Richardson. "Full-Contact Practice and Injuries in College Football," Sports Health 8 (2016): 217-223.

37. L. Kearns, K. Bachynski, and A. L. Caplan, "Add Covid-Related Myocarditis, Mechanical Ventilation, and Death to This Year's Football Risks," Stat Neres, November 26, 2020, available at <https://www.statnews.com/2020/11/26/myocarditismechanical-ventilation-death-join-football-risks-covid-19/> (last visited July 3, 2021).

38. J. Branch, "Solving a Pandemic Puzzle: Inside the Return of Sports to a Power 5 Program," New York Times, September 2, 2020, available at <https://www.nytimes.com/2020/09/02/ sports/ncaafootball/coronavirus-cal-athletics-season.html> (last visited July 3, 2021).

39. H. Bushnell, "Should Teams Actively Seek Herd Immunity from the Coronavirus?" Yahoo Sports, June 30, 2020, available at <https://www.yahoo.com/lifestyle/should-teams-activelyseek-herd-immunity-from-the-coronavirus-234449908.html> (last visited July 3, 2021).

40. B. Senkiw, "Swinney: 'COVID was Just an Excuse to Cancel Game’ by Florida State," Sports Illustrated, November 22, 
2020, available at <https://www.si.com/college/clemson/ football/swinney-covid-was-just-an-excuse-to-cancel-gameat-florid-state> (last visited July 3, 2021).

41. M. Schlabach, "Nick Saban's Daughter Apologizes for Tweet Accusing Ohio State of Using COVID-19 Excuse to Postpone CFP Title Game so Justin Fields Can Heal," ESPN, January 5, 2021, available at <https://www.espn.com/college-football/ story/_/id/30658747/nick-saban-daughter-apologizes-tweetaccusing-ohio-state-using-covid-19-excuse-postpone-titlegame-justin-fields-heal> (last visited July 3, 2021).

42. A. Blinder, L. Higgins, and B. Guggenheim, "College Sports Has Reported at Least 6,629 Virus Cases. There Are Many More," New York Times, December 11, 2020, available at <https://www.nytimes.com/2020/12/11/sports/coronaviruscollege-sports-football.html> (last visited July 3, 2021).

43. D. M. Hale, "Clemson Tigers' Justin Foster Retires From Football, Citing Issues With Asthma, COVID-19," ESPN, February 24, 2021, available at <https://www.espn.com/collegefootball/story/_/id/30958869/clemson-justin-foster-retiresciting-issues-asthma-covid-19> (last visited July 3, 2021)

44. K. Bachynski, "How COVID-19 in 2020 Could Impact the Future of Sports," The Aspen Institute, December 22, 2020, available at <https://www.aspeninstitute.org/blog-posts/howcovid-19-in-2020-could-impact-the-future-of-sports/> (last visited July 3, 2021).

45. P. Hruby, "The Coronavirus Shows How the NCAA Isn't Built to Protect Athletes," Hreal Sports, July 2020, available at <https://www.patrickhruby.net/2020/07/the-coronavirusshows-how-ncaa-isnt.html> (last visited July 3, 2021)

46. A. Liptak and A. Blinder, "Supreme Court Backs Payments to Student-Athletes in N.C.A.A. Case," New York Times, June 21 2021, available at <https://www.nytimes.com/2021/06/21/ us/supreme-court-ncaa-student-athletes.html> (last visited July 3, 2021).

47. A. de Vogue and C. Duster, "Supreme Court Rules Against NCAA, Opening Door to Significant Increase in Compensation for Student Athletes," CBS 58, June 21, 2021, available at <https://www.cbs58.com/news/supreme-court-rules-againstncaa-opening-door-to-significant-increase-in-compensationfor-student-athletes> (last visited July 3, 2021).

48. A. Kostka, "With Jordan McNair in Mind, Father Advocates for Inclusion of Health Guidelines in National NIL Bill," Washington Times, June 18, 2021, available at <https://www. washingtontimes.com/news/2021/jun/18/martin-mcnairadvocates-for-health-and-safety-guid/> (last visited July 3 , 2021).

49. See Bachynski, supra note 44

50. W.L. Howard, "Football and Moral Health," Medical Record 69, no. 14 (1906): 546 . 